\title{
Electroflotation extraction of carbon material powders in the presence of metal ions
}

\author{
A. M. Gaydukova, Cand. Eng., Associate Prof., Dept. "Technologies of inorganic substances and electrochemical \\ processes", e-mail: agaydukova@muctr.ru \\ V. A. Kolesnikov, Dr. Eng., Prof., Head of Dept. "Technologies of inorganic substances and electrochemical processes" \\ V. A. Brodskiy, Cand. Chem., Associate Prof., Dept. "Technologies of inorganic substances and electrochemical \\ processes", e-mail: vladimir_brodsky@mail.ru \\ A. V. Kolesnikov, Cand. Eng., Associate Prof., Dept. "Innovative materials and corrosion protection"l, \\ e-mail: artkoles@list.ru
}

${ }^{1}$ Mendeleev University of Chemical Technology of Russia, Moscow, Russia

Investigations of extraction process for carbon materials after sorption purification of aqueous solutions via elec-
troflotation method with removal of ions of heavy and non-ferrous metals are presented in this work. The data
on adsorption of some organic compounds on "OU-B" carbon material powders and aluminium hydroxides are
observed. The research results of Fe (III) cations (coagulant) influence on extraction efficiency of "OU-A" carbon
materials from aqueous solutions are observed. The effect of metal pH and cation nature on surface parameters of
carbon material particles, specifically on electrokinetic potential is studied. It is shown that extraction completeness
and efficiency depend directly on the value of electrokinetic potential of coal particles; the particles with minimal
absolute surface charge value are extracted mostly completely and effectively, if Fe ${ }^{3+}$ ions are presented in solution.
It was determined that size of particles also has the effect on their extraction efficiency. Based on the obtained data
of electrokinetic potential of particles, a flocculant was selected; if it is added to the solution, the range of carbon
material extracting concentrations expands to $1 \mathrm{~g} / \mathrm{l}$. Based on the obtained data on the electrokinetic potential of
the particles, a flocculant was selected, which, when adding it to the solution, expands the range of recoverable con-
centrations of carbon material to $1 \mathrm{~g} / \mathrm{l}$. The technological scheme of carbon materials use for purification of waste
water using various extraction technologies for dispersed phase is presented. Key words: waste water, electroflotation, powders, activated carbon, sorption of organic compounds, surfactants, metal ions, coagulants.

DOI: $10.17580 /$ cisisr.2021.02.19

\section{Introduction}

Emitted or insufficiently purified waste water from the most of enterprises, as well as production wastes of minerals development in mining plants, water from mines and pits are considered as the main sources of contamination of water basins. Inorganic and organic compounds, nonferrous metals ions are presented in waste water of electroplating-chemical production; they should be extracted using the modern methods. Sorption extraction of harmful components from waste water with various compositions has especial interest owing to its acceptability and absence of secondary contaminations. Activated coals (AC) are widely used in different scientific branches as carbon sorbents; among other applications, they are used in technological processes of adsorption purification, separation, extraction and concentration of various substances in gaseous and liquid media [1-5]. Waste water processing by carbon sorbent directly in the volume of processed liquid is one of the efficient methods of water purification [6-10]. However, use of this method is complicated due to the problems of consequent carbon sorbent separation from purified water. Analysis of technical literary sources displayed that sedimentation and filtration, mainly combined with coagulation and flocculation, are the main methods for carbon material separation from purified water; sediment tanks, tissue filters and membrane systems are used rarely.

Retention is the most simple method for separation of fine-comminuted active coal from liquid phase. However, it is used very rarely due to its large duration (more than two hours). Forming of large and dense flakes during additional introduction of flocculants and coagulants in solution has a serious influence on particles deposition in the process of sedimentation [11]. Coagulant concentration in purification plants at large production facilities can reach in this case the range from $1 \mathrm{~g} / \mathrm{m}^{3}$ [8] to $10 \mathrm{~g} / \mathrm{m}^{3}$ [7, 12]. The effect of coagulant nature on the process efficiency is noted in the work [13].

Filtration is also used for coal separation from purified liquid. This method has several disadvantages, such as necessity of often replacement and regeneration of filtering materials, selection of filters for different sizes of particles.

It is known from the technical literature that flotation method can be used for extraction of carbon materials, i.e. using various organic additives [14, 15]. However, it was established that extraction of carbon material via flotation is restricted sue to application of high coagulant concentrations or organic additives; at the same time, extraction degree of activated coal particles does not reach high values. 
Taking into account the above-described information, it is evident that the new researches in the field of extraction of high-dispersed carbon materials from aqueous solutions after sorption processing of water should be conducted, and it is considered as very actual task. In this work electroflotation method was used for solving this problem. It should be mentioned that there is lack of information in the technical literature about electroflotation application for carbon sorbent extraction. The work [16] is devoted to examination of the combined method based on combination of electroflotation and electric coagulation processes for extraction of pulverized coal. The results showed that efficiency of sorbent extraction depends on the amount of introduced coal and its size, current density and process duration.

Scientific investigations, practice and operation experience revealed several undoubted advantages of the electroflotation method. The main of them are possibility of simultaneous extraction of contaminants having various phase-dispersed composition; relatively low electric power consumption (in comparison with electric coagulation from 0.1 to $0.3 \mathrm{kWt} \cdot \mathrm{h} / \mathrm{m}^{3}$ ); forming of fine-dispersed gaseous bubbles (with diameter 20-60 $\mu \mathrm{m}$ ) with high adhesion capacity to extracted contaminants and able to extract the particles with size about 15-20 $\mu \mathrm{m}$ [17].

The aim of this work is examination of the process of electroflotation extraction of processed carbon powder-type sorbents.

\section{Methods and materials}

Pulverized activated coal of "OU-A" and "OU-B" brands was selected as the object for investigation. This is active, brightened charcoal in powder form, with high porosity and large value of specific absorbing surface. Such coal brands are used in brightening and purification of liquid media. Selection of carbon material concentration depends on initial content of contaminants and preset degree of clowering of concentration of harmful impurities. Waste disposal plants usually use low-concentrated coal (up to $20-50 \mathrm{~g} / \mathrm{m}^{3}$ ) due to appearing difficulties of its consequent separation during filtrating purification. The resarch in this work was conducted on simulated solutions with coal concentration $100-1000 \mathrm{~g} / \mathrm{m}^{3}$. To approximate the simulated solutions to real waste water, background salt $\mathrm{kg} / \mathrm{m}^{3} \mathrm{NaCl}$ and $1 \mathrm{~kg} / \mathrm{m}^{3} \mathrm{Na}_{2} \mathrm{SO}_{4}$, metal cations $\left(\mathrm{Fe}^{3+}, \mathrm{Al}^{3+}, \mathrm{Ni}^{2+}, \mathrm{Ba}^{2+}, \mathrm{Mg}^{2+}, \mathrm{Ca}^{2+}\right)$ with concentration $15-25 \mathrm{~g} / \mathrm{m}^{3}$, as well as organic compounds - surface ac-

\begin{tabular}{|c|c|c|c|c|c|c|c|c|}
\hline rokinetic potential $(\zeta)$ of ca & & & & & & & & \\
\hline Composition of the solution & & & ectrol & kinetic & potent & ial $\zeta$, & & \\
\hline $\mathrm{pH}$ & 4 & 5 & 6 & 7 & 8 & 9 & 10 & 11 \\
\hline $1 \mathrm{~kg} / \mathrm{m}^{3} \mathrm{NaCl}$ & -4 & -4 & -6 & -6 & -7 & -8 & $-9,5$ & -10 \\
\hline $1 \mathrm{~kg} / \mathrm{m}^{3} \mathrm{NaCl}+25 \mathrm{~g} / \mathrm{m}^{3} \mathrm{Fe}^{3+}$ & 1.5 & 2 & 2 & 3 & -0.5 & -2 & -3 & -4 \\
\hline $1 \mathrm{~kg} / \mathrm{m}^{3} \mathrm{Na}_{2} \mathrm{SO}_{4}$ & -29 & -28 & -30 & -31 & -32 & -30 & -30 & -34 \\
\hline $1 \mathrm{~kg} / \mathrm{m}^{3} \mathrm{Na}_{2} \mathrm{SO}_{4}+25 \mathrm{~g} / \mathrm{m}^{3} \mathrm{Fe}^{3+}$ & -1.5 & -4 & -5 & -7 & -9 & -13 & -15 & -19 \\
\hline
\end{tabular}

tive substances (SAS), flocculants $\left(5-10 \mathrm{~g} / \mathrm{m}^{3}\right)$, organic solvents $\left(50-750 \mathrm{~g} / \mathrm{m}^{3}\right)$ were introduced.

The researches were conducted within the range of $\mathrm{pH}$ values 4-10. Waste water of industrial enterprises are characterized by the same $\mathrm{pH}$ average values 4-10 during dumping, depending on the features of production facilities, volume of applied acids $\left(\mathrm{HCl}, \mathrm{H}_{2} \mathrm{SO}_{4}\right)$ and alkalis $\left(\mathrm{NaOH}, \mathrm{Ca}(\mathrm{OH})_{2}\right)$. Lower and higher $\mathrm{pH}$ values (2-3 and $11-12$ respectively) can be met during volley of sewage of processed technological solutions [18].

Experimental investigations of carbon material extraction process were conducted in the landlocked electroflotation unit; its operation principle is described in details in the work [19]. Efficiency of electroflotation process of carbon material extraction from solution was assessed by extraction degree $\alpha(\%)$, which was calculated as relationship of difference between initial and final coal content in solution to its initial content: $\frac{c_{\text {init }}-c_{f i n}}{c_{\text {init }}} \cdot 100 \%$.

Mass coal concentration was measured via turbidimetric method using turbidimeter $\mathrm{HI} 98703$. Concentration of $\mathrm{Fe}^{3+}$ ions was determined by photometry in the presence of sulphosalicylic acid. Optical density of solutions was measures by spectrophotometer SF-2000 on the wave length $500 \mathrm{~nm}$.

$\mathrm{pH}$ control was realized using $\mathrm{pH}$-meter (laboratorial ion meter) I-160MI with combined electrode ESK-10603.

The analyzer Photocor Compact-Z of particles size and zeta potential was used for determination of electrokinetic potential ( $\zeta$-potential) and average hydrodynamic radius of particles.

The values of adsorption $(\mathrm{G}, \mathrm{mg} / \mathrm{g})$ of organic substances on carbon materials and metal hydroxides were determined via the technique [20].

\section{Results and discussion}

It is known that the value of solution $\mathrm{pH}$ has large effect on the process of electroflotation extraction of dispersed phase. Investigations for determination of the effect of medium $\mathrm{pH}$ on extraction degree of carbon materials were conducted in the presence of sodium chloride and sulphate. It was established that efficiency of coal extraction does not vary practically with $\mathrm{pH}$ growth, maximal value of extraction degree in $1 \mathrm{~g} / 1 \mathrm{Na}_{2} \mathrm{SO}_{4}$ and $1 \mathrm{~g} / 1 \mathrm{NaCl}$ solutions does not exceed $13 \%$ and $9 \%$ respectively.

Physical-chemical parameters of extracting particles depend on media acidity. It is known that electrolyte nature has the effect on dispersed phase charge, what influence finally on electroflotation process. The salts of sodium chloride, sulphate and nitrate are met mostly often in waste water. The experimental data about the effect of nature of solution $\mathrm{pH}$, background salt $\left(\mathrm{NaCl}, \mathrm{Na}_{2} \mathrm{SO}_{4}\right)$ and $\mathrm{Fe}^{3+}$ ion on charge of "OU-A" coal dispersed phase particles (Table 1).

It was established that $\mathrm{SO}_{4}{ }^{2-}$ ions are characterized by specific adsorption and strongly vary the value of electrokinetic potential. Inorganic compounds which 
are adsorbing by carbon materials or presenting in solution, can also influence on coal surface charge. It was established that varying the charge value of particles surface promotes increase of extraction degree of carbon material particles during electroflotation processing in acidic medium with pH 4-5 in the conditions of $\mathrm{Fe}^{3+}$ ions presence in the solution (Fig. 1).

It should be noted that "OU-A" active coal is mostly completely extracted during the first 5 minutes since the process beginning, in the presence of coagulant separately and jointly with SAS of cation and anion types. As soon as the process duration increases, the foamy layer is destroying, circulation of dispersed phase occurs and, respectively, efficiency of coal extraction decreases. Contrary to this, introduction of $\mathrm{Fe}^{3+}$ - flocculant $\mathrm{C}-496$ composition in the researching system allows to reach high extraction degree $(\alpha=91 \%)$ just after 20 minutes of electroflotation processing of the solution. Foam is stable and does not destroy as time passes.

It is known that observance of sizes relationships for particles and gas bubbles is required for effective particle catching by such bubble. Low efficiency of the process of carbon solvent extraction from solutions without organic and inorganic additives is connected perhaps with small size of particles. The investigations for determination of the average hydrodynamic radius of particles were conducted. It was found out that the size of dispersed phase particles does not vary substantially with increase of solution $\mathrm{pH}$ value and makes 11-16 $\mu \mathrm{m}$. Introduction of metal cations in the solution has no effect on size of particles.

Organic flocculants are added in the solution to enlarge the particles. Adsorption of flocculants on hydrophilic surface of particles modifies this surface and makes it more hydrophobic; it provides more easy process of bubble fixing on a particle. It was established that addition of cation-type flocculant promotes more complete extraction of pulverized coal from the solution in $\mathrm{pH}$ range within 4-8 (Fig. 2).

Forming of large floccules was observed after addition of the organic additive; they were effectively extracted later during electroflotation process.

It is known, that the more amount of sorbent will be added in the processing solution, the higher will be efficiency of its purification with removal of toxic impurities. Thereby the researches were conducted for determination of the amount of extracted coal during electroflotation process (Table 2).

It was established that up to $1 \mathrm{~g} / 1$ of carbon solvent can be extracted from the solution containing metal cation and organic additive. It should be mentioned that residual concentration of Fe (III) ions does not exceed $0.1 \mathrm{mg} / \mathrm{l}$.

In addition to $\mathrm{Fe}$ (III) ions, waste water can also contain other metal ions, depending on production features. Investigations on influence of metal cations $\left(\mathrm{Ni}^{2+}, \mathrm{Al}^{3+}, \mathrm{Ba}^{2+}, \mathrm{Mg}^{2+}\right)$ on the value and sign of electrokinetic potential of carbon material particles were conducted. It was found out that carbon material particles are charged negatively within the whole range $\mathrm{pH}=4-11$ in the solutions containing metal cations.
When $\mathrm{pH}=4-7$, the value of $\xi$-potential differs from -6 to $-8 \mathrm{mV}$, while if $\mathrm{pH}=11, \xi$-potential is within the range from -10 to $-15 \mathrm{mV}$. A cation-type C-496 flocculant was added in the solution to extract carbon material. It was proven that coal with sorbing metal cations was extracted effectively within the $\mathrm{pH}$ range $6-11(\alpha=80-90 \%)$.

Investigations on sorption extraction of several organic compounds and SAS from waste water of printed circuit

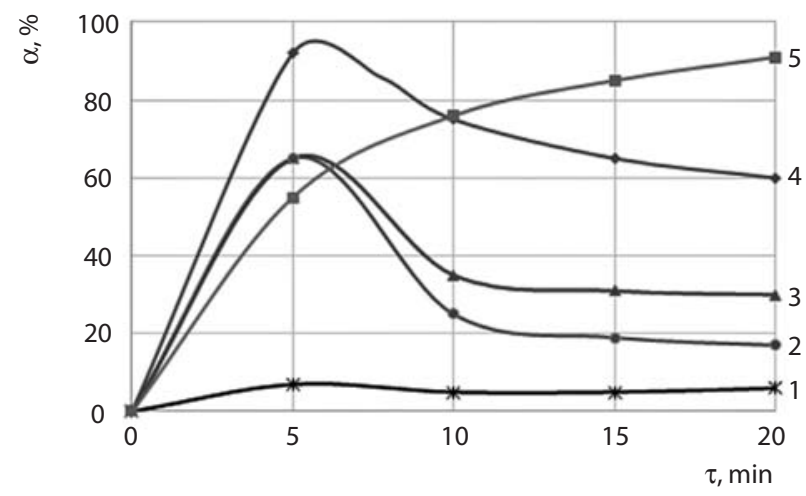

Fig. 1. Influence of various additives on the degree of "OU-A" pulverized coal extraction in the process of electroflotation processing of the solution: 1 - without additives, $2-\mathrm{Fe}^{3+}, 3-\mathrm{Fe}^{3+}-\mathrm{NaDDS}$ composition, $4-\mathrm{Fe}^{3+}$-SeptaPAV (SeptaSAS) composition, $5-\mathrm{Fe}^{3+}-\mathrm{C}-496$ composition; $c(\mathrm{NaCl})=1 \mathrm{~kg} / \mathrm{m}^{3}$, $\mathrm{c}_{\mathrm{AU}}=200 \mathrm{~g} / \mathrm{m} 3, i=0,4 \mathrm{~A} / 1, c\left(\mathrm{FeCl}_{3}\right)=25 \mathrm{~g} / \mathrm{m}^{3}$, $c$ (org. add. $)=5 \mathrm{~g} / \mathrm{m}^{3}, \mathrm{pH} 4$

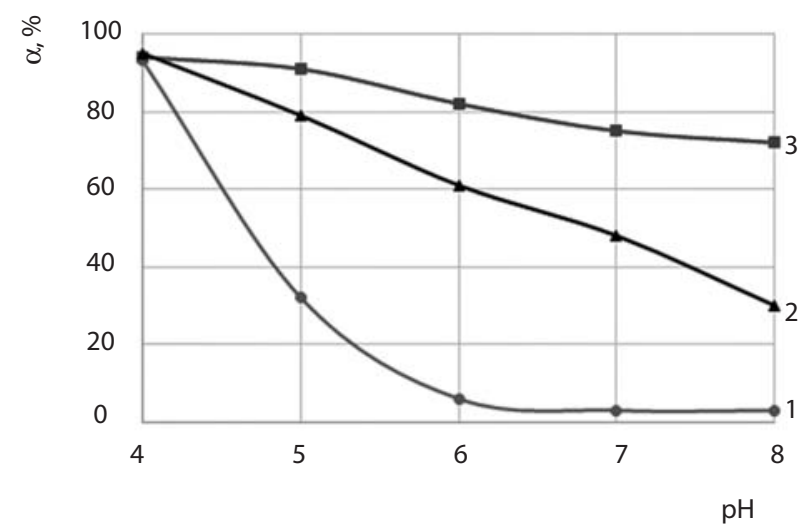

Fig. 2. Dependence between carbon material extraction degree and solution $\mathrm{pH}$, containing $\mathrm{Fe}^{3+}$ cations: 1 - without organic additive, 2 - with SeptaPAV (SeptaSAS) addition; 3 - with $\mathrm{C}-496$ flocculant addition; $c_{\mathrm{AU}}=200 \mathrm{~g} / \mathrm{m}^{3}, i=0,4 \mathrm{~A} / 1, c\left(\mathrm{Fe}^{3+}\right)=25 \mathrm{~g} / \mathrm{m}^{3}, \mathrm{pH} 4$, $c$ (org. add. $)=5 \mathrm{~g} / \mathrm{m}^{3}$
Table 2. Degree of carbon material extraction from the solution containing metal ions and C-496 flocculant, depending on its concentration for $\mathrm{pH}=4$, and residual concentration of $\mathrm{Fe}^{3+}$ ions in the solution after electroflotation

\begin{tabular}{|l|c|c|c|c|c|c|c|c|c|}
\hline $\mathrm{C}_{\text {init }} \mathrm{AU}, \mathrm{g} / \mathrm{m}^{3}$ & 200 & 300 & 400 & 500 & 600 & 700 & 800 & 900 & 1000 \\
\hline
\end{tabular}

\begin{tabular}{|l|c|c|c|c|c|c|c|c|c|c|}
\hline$\alpha \mathrm{AU}, \%$ & 90 & 90 & 89 & 89 & 88 & 88 & 87 & 86 & 84 \\
\hline
\end{tabular}

\begin{tabular}{|l|l|l|l|l|l|l|l|l|l|}
\hline $\mathrm{C}_{\text {fin }} \mathrm{Fe}^{3+}, \mathrm{g} / \mathrm{m}^{3}$ & $<0,1$ & $<0,1$ & $<0,1$ & $<0,1$ & $<0,1$ & $<0,1$ & $<0,1$ & $<0,1$ & $<0,1$ \\
\hline
\end{tabular}

$\mathrm{c}($ floc. $)=5 \mathrm{~g} / \mathrm{m}^{3}$, iv $=0,4 \mathrm{~A} / \mathrm{l} ; \mathrm{c}(\mathrm{NaCl})=1 \mathrm{~kg} / \mathrm{m}^{3} ; \tau=20 \mathrm{~min}$ 


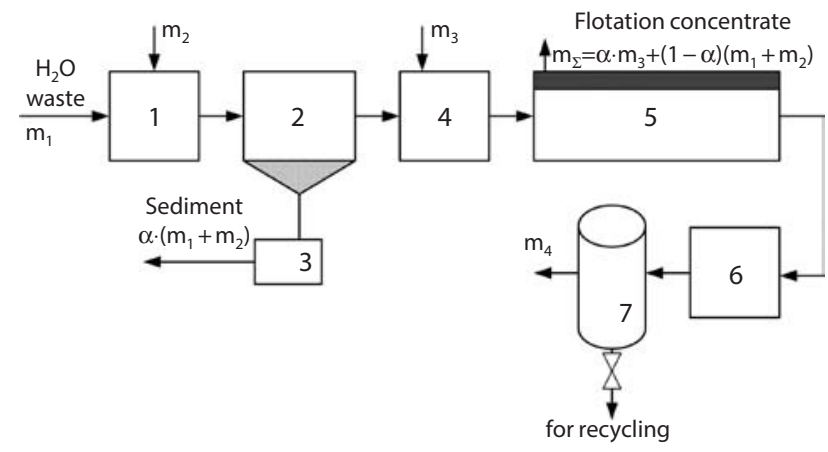

Fig. 3. Scheme of multi-stage waste water purification using sorbents and with removal of contaminants: 1 - container for mixing; 2 - thin-wall sediment tank; 3 - filter press; 4 - container for mixing; 5 - electroflotator; 6 - microfilter; 7- column with activated coal.

Sorbents: $\mathrm{m}_{1} \rightarrow$ hydroxides $\mathrm{Me}^{2+/ 3+}(\mathrm{Fe}, \mathrm{Al}, \mathrm{Cr}, \mathrm{Cu}, \mathrm{Zn}$, $\mathrm{Ni}$ etc.); $\mathrm{m}_{2} \rightarrow \mathrm{OU}-\mathrm{A}(\mathrm{OU}-\mathrm{B}), \mathrm{Al}^{3+}, \mathrm{Fe}^{3+} ; \mathrm{m}_{3} \rightarrow \mathrm{OU}-\mathrm{A}$ $(\mathrm{OU}-\mathrm{B})+\mathrm{Al}^{3+} ; \mathrm{m} \sum=\alpha \cdot \mathrm{m}_{3}+(1-\alpha) \cdot\left(\mathrm{m}_{1}+\mathrm{m}_{2}\right) ; \mathrm{m}_{4}-$ sorption charge of filter (OU-A). Dosing of sorbents is conducted on the stages 1,4 and 7

production and electroplating-chemical processes were conducted on pulverized "OU-B" coal and $\mathrm{Al}(\mathrm{OH})_{3}$ (Table 3).

Comparison of SAS sorption value on $\mathrm{Al}(\mathrm{OH})_{3}$ sediments and "OU-B" pulverized coals shows that this value in the first case is essentially higher than that for carbon sorbents, what is connected with difficulties of SAS penetration in coal micro-pores. The main places for SAS sorption are meso-pores, located on coals surface. We can see that the adsorption values for aluminium hydroxide are higher, when calculated for $1 \mathrm{~g}$ of sorbent, in comparison with "OU-B" powders; it makes prospective application of $\mathrm{Al}(\mathrm{OH})_{3}$ as coagulants and sorbents during waste water purification with removal of organic contaminants at production areas of printed circuits.

The multi-stage approach using electroflotation technology and 2 types of sorbents (pulverized coal and metal hydroxides), as well as sorption modules, was suggested during development of purification technology for waste water with removal of contaminants (Fig. 3).

Use of the suggested scheme at waste disposal plants of industrial enterprises, i. e. electroplating production facilities, where waste water contain large amounts of contaminants of both organic and inorganic nature, allows to cut the expenses for replacement and regeneration of filtering material, to accelerate purification process (from several days to $10-20 \mathrm{~min}$ ), as well as to rise waste water purifica-

Table 3. Influence of adsorbent nature on adsorption value of organic compounds

\begin{tabular}{|c|c|c|c|c|c|c|c|c|}
\hline \multirow{2}{*}{$\begin{array}{c}\mathrm{C}_{\text {init. }} \\
\mathrm{g} / \mathrm{m}^{3}\end{array}$} & \multicolumn{8}{|c|}{$\mathrm{G}, \mathrm{mg} / \mathrm{g}$} \\
\cline { 2 - 9 } & monoethanolamine & \multicolumn{2}{|c|}{ butylglycol } & \multicolumn{2}{c|}{ butanol } & \multicolumn{2}{c|}{ dimethylformamide } \\
\cline { 2 - 9 } & $\mathrm{Al}(\mathrm{OH})_{3}$ & OU-B & $\mathrm{Al}(\mathrm{OH})_{3}$ & $\mathrm{OU}-\mathrm{B}$ & $\mathrm{Al}(\mathrm{OH})_{3}$ & $\mathrm{OU}-\mathrm{B}$ & $\mathrm{Al}(\mathrm{OH})_{3}$ & $\mathrm{OU}-\mathrm{B}$ \\
\hline 250 & 1090 & 290 & 730 & 390 & 440 & 150 & 540 & 130 \\
\hline 500 & 1430 & 340 & 800 & 450 & 940 & 550 & 1150 & 290 \\
\hline 750 & 1620 & 720 & 820 & 400 & 1030 & 500 & 1700 & 300 \\
\hline
\end{tabular}

tion efficiency due to including electroflotation module in the technological route.

\section{Conclusions}

It was established that physical-chemical parameters of extracting particles (such as electrokinetic potential and average hydrodynamic radius) influence on extraction efficiency of powder-type carbon sorbents via electroflotation method. Positive effect of Fe (III) cations on efficiency of electroflotation process due to shift of electrokinetic potential of particles in the more positive area within acidic medium was noted. The coal extraction degree lowers with elevation of solution $\mathrm{pH}$. Low extraction degree is connected with small size of dispersed phase particles; as a result, these particles are not caught by gaseous bubbles, which are forming on electrodes, and forming of the flotation complex "coal gas bubble" does not occur, while it is considered as the determining stage of electroflotation process. Parameters on the average hydrodynamic radius of the particles were obtained depending on solution $\mathrm{pH}$. It was found out that increase of the $\mathrm{pH}$ value for solution does not lead to essential variation of size of dispersed phase particles, and this size makes $11-16 \mu \mathrm{m}$. It was determined that additional introduction of cation-type flocculant in the solution promotes enlargement of particles and thereby efficient forming of flotation complex. In this connection, if we know the value and sign of electrokinetic potential of particles, we can choose an organic addition (flocculant) for enlargement of particles and their additional extraction by gaseous bubbles which are forming during electrolysis.

It was revealed that organic additives of various nature are subjected to sorption on coals with insufficient efficiency and don't lead to increase of extraction degree of carbon materials via electroflotation method. It is explained by different sediment structure, by presence of pores (coals) which are not accessible for large molecules, by physical-chemical properties and electronic parameters of metals in the components structure. However, it was found out based on the conducted investigations that extraction degree increases substantially in the case of addition of coagulants. These coagulants are based on $\mathrm{Fe}^{3+}$ and $\mathrm{Al}^{3+}$ salts, which form sediments of hydroxides in the $\mathrm{pH}$ range $4-10$; they catch the particles (oxides, carbides, "OU-B" etc.) and enlarge the size, what finally intensifies the processes of flotation and sedimentation.

Based on the conducted researches, the scheme of multistage purification of waste water is suggested. Use of electroflotation method in the technological process allows to accelerate substantially the extraction process of carbon materials from several hours to $10-20$ min with minimal power consumption.

The results of investigations present the practical interest for improvement of technological processes of waste water purification with removal 
of carbon sorbents. It is achieved via sorption purification in the volume of processing solution at waste disposal plant of most industrial production facilities (in particular, electroplating production). The above-mentioned approach of use of powder-type carbon materials for purification of waste water and technological solutions was applied in 2020 during designing of four FEO (Federal ecological operator) objects, where deactivation of liquid wastes having I-II danger class is planned [18]. The state specialized designing institute (GSPI) and Mendeleev University of Chemical Technology of Russia (RCTU) participated in this project.

The research was conducted under financial support of Mendeleev University of Chemical Technology of Russia (project No. 3-2020-003).

\section{REFERENCES}

1. Moreno Castilla C. Adsorption of Organic Molecules from Aqueous Solutions on Carbon Materials. Carbon. 2004. Vol. 42. pp. 83-94. DOI: 10.1016/j.carbon.2003.09.022.

2. Gupta V. K., Saleh T. A. Sorption of pollutants by porous carbon, carbon nanotubes and fullerene - An overview. Environmental Science and Pollution Research, 2013. Vol. 20. pp. 2828-2843. DOI: $10.1007 / \mathrm{s} 11356-013-1524-1$.

3. Upadhyayula Venkata K. K., Deng S., Mitchell M. C., Smith G. B. Application of carbon nanotube technology for removal of contaminants in drinking water: A review. Science of The Total Environment. 2009. Vol. 408. pp. 1-13. DOI: 10.1016/j.scitotenv.2009.09.027.

4. Siriwardane R. V., Shen Ming-Shing, Fisher E. P., Poston J. A. Adsorption of $\mathrm{CO}_{2}$ on Molecular Sieves and Activated Carbon. Energy \& Fuels. 2001. Vol. 15 (2). pp. 279-284. DOI: 10.1021/ ef000241s.

5. Alaei Shahmirzadi M. A., Hosseini S. S., Luo J., Ortiz I. Significance, evolution and recent advances in adsorption technology, materials and processes for desalination, water softening and salt removal. Journal of Environmental Management. 2018. Vol. 215. pp. 324-344. DOI:10.1016/j.jenvman.2018.03.040

6. Hu J., Aarts A., Shang R., Heijman B., Rietveld L. Integrating powdered activated carbon into wastewater tertiary filter for micro-pollutant removal. Journal of Environmental Management. 2016. Vol. 177. pp. 45-52. DOI: 10.1016/j.jenvman.2016.04.003.

7. Margot J., Kienle C., Magnet A., Weil M., Rossi L., Felippe de Alencastro L., Abegglen C., Thonney D., Chèvre N., Schärer M., Barrya D. A. Treatment of micropollutants in municipal wastewater: Ozone or powdered activated carbon? Science of The Total Environment. 2013. Vol. 461-462. pp. 480-498. DOI: 10.1016/j. scitotenv.2013.05.034.
8. Löwenberg J., Zenker A., Krahnstöver T., Boehler M., Baggenstos M., Koch G., Wintgens T. Upgrade of deep bed filtration with activated carbon dosage for compact micropollutant removal from wastewater in technical scale. Water Research. 2016. Vol. 94. pp. 246-256. DOI: 10.1016/j.watres.2016.02.033.

9. Mukhin V. M. Environmental Aspects of Activated Carbon Application. Ecology and Industry of Russia. 2014. No. 12. pp. 52-56. DOI: $10.18412 / 1816-0395-2014-12-52-56$.

10. Mukhin V. M. Research of quality of active coals used in water purification. Vodoochistka. Vodopodgotovka. Vodosnabzhenie. 2010. No. 9. pp. 34-36.

11. Krahnstöver T., Wintgens Th. Separating powdered activated carbon (PAC) from wastewater - Technical process options and assessment of removal efficiency. Journal of Environmental Chemical Engineering, 2018. Vol. 6 (5), pp. 5744-5762. DOI: 10.1016/j. jece.2018.09.001.

12. Meinel F., Zietzschmann F., Ruhl A., Sperlich A., Jekel M. The benefits of powdered activated carbon recirculation for micropollutant removal in advanced wastewater treatment. Water Research. 2016. Vol. 91. pp. 97-103. DOI: 10.1016 / j. watres.2016.01.009.

13. Luo Y., Guo W., Ngo H. H., Nghiem L. D., Hai F. I., Zhang J., Liang S., Wang C. X. A review on the occurrence of micropollutants in the aquatic environment and their fate and removal during wastewater treatment. Science of the Total Environment. 2014. Vol. 473. pp. 619-642. DOI: 10.1016/j.scitotenv.2013.12.065.

14. Chen S., Tang L., Tao X., He H., Chen L. Exploration on the mechanism of oily-bubble flotation of long-flame coal. Fuel. 2018. Vol. 216. pp. 427-435. DOI: 10.1016/j.fuel.2017.10.126.

15. Chen P., Li H., Yi H., Jia F., Song S. Removal of graphene oxide from water by flocflotation. Separation and Purification Technology. 2018. Vol. 202. pp. 27-33. DOI: 10.1016/j.seppur.2018.03.034.

16. Vu T. P., Vogel A., Kern F., Platz S., Menzel U., Gadow R. Characteristics of an electrocoagulation-electroflotation process in separating powdered activated carbon from urban wastewater effluent. Separation and Purification Technology. 2014. Vol. 134. pp. 196-203. DOI: 10.1016/j.seppur.2014.07.038.

17. Kolesnikov A. V., Than So Htay, Kolesnikov V. A., Kovalenko V. S. Extraction by electroflotation of iron, chromium and aluminium hydroxides from aqueous solutions of sodium chlorides and sulphates in the presence of $\mathrm{Mg}^{2+}, \mathrm{Ca}^{2+}$ and surfactants of different types. CIS Iron and Steel Review. 2020. Vol. 20. pp. 61-65. DOI: 10.17580/cisisr.2020.02.13.

18. Mazhuga A. G., Kolesnikov V. A., Sakharov D. A., Korolkov M. V. Man-caused wastes of I-II danger classes - a resource for fabrication of secondary products. Teoreticheskaya i prikladnaya ekologiya. 2020. No. 4. pp. 61-67.

19. Gaydukova A., Kolesnikov V., Stoyanova A., Kolesnikov A. Separation of highly dispersed carbon material of OU-B grade from aqueous solutions using electroflotation technique. Separation and Purification Technology. 2020. Vol. 245. 116861. DOI: 10.1016/j.seppur.2020.116861.

20. Ladygina Yu. Sh., Mets E. A., Kolesnikov A. V. Adsorption of anion surface-active substances on freshly formed sediment of metal hydroxide. Uspekhi v khimii i khimicheskoy tekhnologii. 2017. Vol. 31. No. 6. pp. 46-48. 